\title{
DE ROBESPIERRE A KANT: MME. DE STAËL E A "REVOLUÇÃO ALEMÃ” DA CRÍTICA FRANCESA
}

\author{
Nabil Araújo de Souza*
}

Resumo: Este artigo apresenta e analisa a revolução na crítica literária francesa operada no início do século XIX por Mme. de Staël (1766-1817), na esteira da "revolução kantiana" ocorrida em fins do século XVIII na Alemanha.

Palavras-chave: Revolução francesa; revolução kantiana; juízo de gosto; crítica literária; Mme. de Staël.

Abstract: This article presents and analyses the revolution in French literary criticism operated in the early 19th century by Mme. de Staël (1766-1817), in the wake of the "Kantian revolution" occurred in the late 18th century in Germany.

Keywords: French revolution; Kantian revolution; judgement of taste; literary criticism; Mme. de Staël.

* Universidade Federal de Minas Gerais. 
Em sua célebre Histoire de la littérature française (1894), Gustave Lanson toma a Revolução Francesa como marco inaugural do que chama de "época contemporânea" das letras de seu país. Poder-se-ia considerar que, ao fazê-lo, ele apenas cedia comodamente a algo que já havia se convertido em praxe historiográfica no momento em que escreve seu grande livro, mas, a julgar por seus próprios ensinamentos na matéria, a história literária digna do nome é regida por um interesse prioritariamente histórico-literário, e não meramente histórico, de modo que o papel da Revolução de 1789 para a instituição de algum pretenso "nouveau régime" no campo literário francês precisaria ser devidamente justificado.

Um efeito revolucionário importante nesse sentido destacado por Lanson é o que ele chama de "ruína da sociedade polida", e a consequente substituição de um ideal letrado aristocrático por um ideal letrado democrático por ela promovida, bem como as consequências educacionais dessa mudança: "o que sustentava o gosto clássico", pondera, com efeito, Lanson (1912, p. 854-855), "[era] uma aristocracia de privilegiados tão bem dispensada de especializações e ações profissionais que via a marca das mesmas como desqualificador do homem honesto: então a educação não podia ter por fim senão o ornamento e o jogo de espírito"; em contrapartida:

a constituição democrática de nossa sociedade deu lugar à educação científica, aos estudos técnicos e especiais, ao lado, mesmo acima das letras puras: o público que julga os livros não é mais homogêneo, e sobretudo, a despeito de nossos programas de instrução, não inclui senão um número bem pequeno de espíritos que tivessem realmente recebido sua forma da antiguidade (Ibid., p. 855).

Mas o desaparecimento do letrado aristocrático que se comprazia em exibir seu "bon goût" nos salões parisienses prérevolucionários não implicou por si mesmo e imediatamente o surgimento do letrado republicano que busca fundamentar e 
justificar seu juízo de gosto com base numa "educação científica" democraticamente instituída. Juntamente com o mundo aristocrático, observa Lanson, "a Revolução levou o gosto clássico" (Ibid., p. 854); e não pôs nada em seu lugar, poder-se-ia acrescentar, a julgar pela literatura que se passa a produzir, segundo Lanson, com a instauração da nova ordem a partir de 1789: "mais livre do gosto mundano, do espírito, da análise, da finura picante, menos inteligente, ela se esvaziou de pensamento harmonizando suas formas" (Ibid., p. 855); e ainda: "a elegância antiga da literatura do primeiro Império não é senão um frio pastiche, uma cópia desinteligente de formas estrangeiras" (Ibid., p. 855). Bem entendido, a renovação radical no campo político não teria sido capaz de engendrar por si só uma renovação análoga no campo literário.

De acordo com o traçado da Histoire lansoniana, foi preciso esperar, quanto a isso, pela atuação decisiva do primeiro grande nome da crítica francesa da "Época contemporânea", ironicamente o de uma aristocrata fortemente entusiasta da Revolução de 1789: nascida Anne-Louise Germaine Necker, mais tarde baronesa de Staël-Holstein, a célebre Madame de Staël encarnaria, assim, o ponto de inflexão na origem do horizonte de contemporaneidade crítica no qual se insere o próprio Lanson. "O papel de Mme. de Staël, em literatura, foi o de compreender e fazer compreender", sentencia Lanson (Ibid., p. 881), acrescentando:

Endereçando-se à inteligência de seus contemporâneos, ela a obriga a se instruir, injeta-lhe ideias que a enlarguecem; legitima por toda a sorte de finas de considerações as aspirações novas de que as almas estavam atormentadas e às quais o gosto tradicional recusava a livre passagem na literatura. Ela coloca, assim, os princípios de um gosto novo (Ibid., p. 881).

Isso se dará, basicamente, por efeito de dois livros capitais da autora nos quais tradicionalmente se reconhece o grande impulso inaugurador do romantismo na França. O primeiro deles 
é De la littérature (1800), livro que, como bem observa Lanson (Ibid., p. 881), é "mais claro no detalhe do que no conjunto". Na primeira das duas grandes partes em que se divide, que tem a forma geral de um panorama retrospectivo "De la littérature chez les anciens et chez les modernes" [Da literatura entre os antigos e entre os modernos], chama especialmente a atenção o único capítulo cujo título é uma pergunta: "Pourquoi la nation française était-elle la nation de l'Europe qui avait le plus de grâce, de goût et de gaieté?" [Por que a nação francesa era a nação da Europa que tinha mais graça, gosto e alegria?] A resposta fornecida pela autora opera, logo de partida, uma radical desnaturalização da noção de bom gosto sobre a qual assentava o "ancien régime" da crítica francesa: "A alegria francesa, o bom gosto francês", pondera Staël (1991, p. 271), "tornaram-se um modelo em todos os países da Europa, e se atribuía geralmente esse gosto e essa alegria ao caráter nacional: mas o que é um caráter nacional se não o resultado das instituições e das circunstâncias que influem sobre a felicidade de um povo, sobre seus interesses e seus hábitos?"

Staël procura explicar, então, na sequência, a excepcionalidade francesa em matéria de gosto em função da especificidade do sistema monárquico francês: "Havia em outros países governos monárquicos, reis absolutos, cortes suntuosas", observa Staël (Ibid., p. 272), "mas em nenhuma parte encontravam-se reunidas as mesmas circunstâncias que influíam sobre o espírito e os costumes dos franceses". Apenas na França, segundo Staël (Ibid. p. 273), a autoridade dos reis sendo consolidada pelo consentimento tácito da nobreza, o monarca desfrutava de um poder a um só tempo sem limites, pelo fato, e incerto, pelo direito, o que o obrigava a tratar seus cortesãos "como fazendo parte desse corpo de vencedores que ao mesmo tempo lhe cedia e lhe garantia a França, conquista deles". Os nobres prestigiados pelo rei viam-se obrigados, em contrapartida, a "decorar a submissão a mais devotada com as formas da liberdade"; assim: 
Era necessário que eles conservassem, em suas relações com seu mestre, uma espécie de espírito cavalheiresco, que eles escrevessem sobre seu escudo POR MINHA SENHORA E POR MEU REI, a fim de se dar o ar de escolher o jugo que suportavam; e misturando, assim, a honra com a servidão, tentavam se curvar sem se aviltar. A graça era, por assim dizer, na situação deles, uma política necessária; somente ela podia dar qualquer coisa de voluntária à obediência (Ibid., p. 273).

A "alegria picante" [la gaieté piquante], mais do que a "graça polida" [la grâce polie], destaca Staël noutro ponto, "apagava todas as distâncias sem destruir nenhuma; fazia sonhar aos grandes a igualdade com os reis, aos poetas a igualdade com os nobres, e dava mesmo ao homem de uma classe superior um sentimento mais refinado de suas vantagens" (Ibid., p. 275). Num contexto no qual o acesso ao poder não se dava nem pelo trabalho nem pelo estudo, sendo facilitado, antes, por "uma palavra correta, uma certa graça", observa Staël (Ibid., p. 278), parecia natural que se desenvolvesse uma espécie "de filosofia despreocupada, de confiança no acaso, de desprezo pelos esforços estudiosos, que empurrava todos os espíritos para o divertimento e o prazer" (Ibid, p, 278). Em suma: "Quando a diversão é não apenas permitida, mas frequentemente útil, uma nação deve alcançar nesse comportamento aquilo que pode haver de mais perfeito" (Ibid., p. 278). Ora, é justamente esse estado de coisas que havia ruído com a Revolução, podendo a essa altura ser tão diligentemente dissecado justamente por encontrar-se definitivamente morto, como ressalta Staël no último parágrafo do capítulo em questão:

Não se verá mais nada de parecido na França com um governo de outra natureza, de qualquer maneira que ele seja combinado; e estará bem provado, então, que isso a que se chamava o espírito francês, a graça francesa, não era senão o efeito imediato e necessário de instituições monárquicas, tal como existiam na França desde muitos séculos (Ibid., p. 278). 
Essa observação de Staël poderia mesmo soar como a última pá de cal sobre uma então moribunda pretensão de justificar a função crítica do referido "bom gosto" francês com base em sua alegada naturalidade ou racionalidade intrínseca; mas nela está em jogo bem mais do que isso: na verdade, aquilo mesmo que enseja à autora sua desmistificadora análise da "graça", do "gosto" e da "alegria" franceses implica já uma decisiva reorientação da visada crítica: da antiga preocupação com a conformação da literatura a preceitos clássicos ao interesse por desvendar o alicerce social/institucional da produção literária.

O título completo do livro de Staël impõe-se, na verdade, ele próprio, como a enunciação de um promissor programa de pesquisa: De la littérature considérée dans ses rapports avec les institutions sociales [Da literatura considerada em suas relações com as instituições sociais]; como explica a autora logo na abertura de seu livro: "Propus-me a examinar qual a influência da religião, dos costumes e das leis sobre a literatura, e qual a influência da literatura sobre a religião, os costumes e as leis" (Ibid., p. 65). Isso porque, segundo ela, não se havia ainda suficientemente analisado "as causas morais e políticas que modificam o espírito da literatura" (Ibid., p. 65); "observando as diferenças características entre os escritos dos italianos, dos ingleses, dos alemães e dos franceses", ela diz, "acreditei poder demonstrar que as instituições políticas e religiosas tinham a maior parte nessas diversidades constantes" (Ibid., p. 65-66). Lanson (1912, p. 882) identifica nesse programa o "princípio novo, largo, fecundo" que "contém todo o desenvolvimento posterior da crítica". Lanson reconhece em De la littérature um "passo decisivo" dado por Staël: "as literaturas modernas são as literaturas cristãs, e a literatura francesa se colocou em condições desvantajosas impondose as formas e as regras das obras antigas e pagãs", havendo, pois, "literaturas que, melhor do que a nossa, encontraram as verdadeiras condições da beleza literária, porque foram francamente nacionais e cristãs" (Ibid., p. 882). Alguns anos antes (em 1890), Brunetière não hesitava em afirmar, nesse mesmo sentido, que Madame de Staël "fez, 
enfim, triunfarem os modernos"; e se isso ele atribui ao fato de Staël ser mulher - "as mulheres estão sempre do lado dos modernos" (BRUNETIÈRE, 2000, p. 197) -, Lanson, por sua vez, atribuirá o que chama a "inteligência cosmopolita" da autora à sua origem suíça, não-francesa:

Nossos franceses haviam tido ideias, desejo, em teoria: de fato, não foram capazes de sair deles mesmos; seu cosmopolitismo não é senão uma pretensão de reduzir toda a humanidade à sua fôrma. Mas Mme. de Staël não é francesa nesse sentido, e isso porque não é francesa de origem. Os suíços, em contato com a França, com a Itália, com a Alemanha, que os conduzà Inglaterra, parecem ter facilidades e atitudes particulares para compreender as formas de espírito dessas quatro nações: eles têm a inteligência naturalmente cosmopolita (LANSON, 1912, p. 876).

Seja qual for a explicação para a "modernidade" e o "cosmopolitismo" da autora, o fato é que eles engendrarão uma lição de longo alcance para a crítica francesa posterior, que não se cansará de reconhecer em Staël uma espécie de mestra primordial: para Brunetière, ao fazer fundarem-se os caracteres originais do drama inglês ou do romance alemão no que há de mais íntimo no gênio germânico ou anglo-saxão, no mesmo golpe "ela nos ensinava a duvidar das regras da antiga crítica, fundadas que estavam sobre uma experiência literária cuja insuficiência aparecia bruscamente aos olhos de seu leitores" (BRUNETIÈRE, 2000, p. 186); segundo Lanson (1912, p. 883): "ao ideal de Boileau se encontra substituída uma pluralidade de tipos ideais, relativos cada um ao caráter nacional e ao desenvolvimento histórico de cada povo: a tirania das regras eternas é rejeitada".

Mas justamente aí, nessa celebrada conquista, se veria implicada uma importante fragilidade, muito bem definida por Brunetière (2000, p. 187) nos seguintes termos: "A parte do absoluto diminui, aquela do relativo aumenta; e, com ela, consequentemente, a dificuldade de formular em crítica". Mais à 
frente, ele observa que: "A beleza das obras é relativa, para Mme. de Staël, quanto ao tempo, às circunstâncias, à raça, à religião, às leis, aos costumes, à estrutura da sociedade: ela não é mais, para [Victor] Hugo, do que o capricho ou a fantasia do juiz" (Ibid., p. 200). À medida que o romantismo na França teria se confundido com o triunfo "do diletantismo, do individualismo e do subjetivismo" (Ibid., p. 201), a verdadeira crítica não poderia senão lhe fazer oposição: "Ou, antes, e fora dele, paralelamente a ele", pondera Brunetière, "a crítica, prosseguindo sua carreira, iria tentar reduzir a parte dessa relatividade que reconhecia nas coisas"; e ainda: "sob pena de perder seu nome e seu sentido, ela iria tentar encontrar, noutro lugar que não na noção de regras e do belo ideal, seu ponto fixo e regulador - ou, como se diz ainda, o criterium de seus julgamentos" (Ibid., p. 200).

Ora, essa busca é mais do que patente em Mme. de Staël, e não se poderia seriamente tomá-la como se simplesmente prefigurasse o "diletantismo-individualismo-subjetivismo" romântico em matéria de crítica. Como observou o próprio Brunetière, Victor Hugo, a quem ele considera "o espírito menos crítico que certamente houve", "nem sempre compreendeu Mme. de Staël" (Ibid., p. 198), representando mesmo, em relação à autora, um retrocesso: notadamente quando responde a ela, "por esse argumento de colégio, que o belo é sempre e por toda parte o belo, sempre e por toda parte idêntico a si mesmo, o que contradiz, entretanto, muito, a experiência da história - e que é, por outro lado, a negação de toda crítica" (Ibid., p. 200).

Se Staël de fato confere à "experiência da história" um papel central em sua abordagem da literatura, ela não o faz de maneira exclusivamente reconstitutiva, mas também deliberadamente prospectiva, como quem se póe, na verdade, a escrever uma história em vias de acontecimento ou, mesmo, na iminência de acontecer: toda a segunda parte de De la littérature anuncia-se, assim, como uma projeção "De l'état actuel des lumières en France, et de leurs progrès futurs" [Do estado atual das luzes na França, e 
de seus progressos futuros]. O conjunto do que aí dirá, então, Staël enuncia-se à guisa de uma reação imediata da autora aos efeitos da primeira década da Revolução no mundo letrado francês, como fica claro desde as primeiras linhas do primeiro capítulo:

Segui a história do espírito humano de Homero até 1789. Em meu orgulho nacional, via a época da revolução da França como uma nova era para o mundo intelectual. Talvez não passe de um evento terrível! - talvez o império de antigos hábitos não permita que esse evento possa conduzir a longo tempo nem a uma instituição fecunda nem a um resultado filosófico (STAËL, 1991, p. 297).

A leitura desse testemunho sinceramente consternado de Staël em face da esterilidade filosófica da França pós-revolucionária remete à provocativa comparação que fará Heinrich Heine num livro publicado exatos trinta e cinco anos depois, durante seu exílio parisiense, entre a revolução francesa e a "revolução filosófica" alemã, bem como entre os respectivos protagonistas de cada uma das referidas revoluções: Robespierre e Kant. "Para falar a verdade, vocês, franceses, foram doces e moderados comparados a nós, alemães: não puderam matar senão um rei, e ainda lhes foi preciso, nessa ocasião, rufar, vociferar e trepidar a sacudir todo o globo", tripudia, com efeito, Heine (1998, p. 115), e sentencia: "Faz-se, realmente, muita honra a Maximilien Robespierre comparando-o a Immanuel Kant". Mais à frente: "Kant, esse grande demolidor no domínio do pensamento, ultrapassou de longe, em terrorismo, Maximilien Robespierre" (Ibid., p. 116); um pouco antes: "Diz-se que os espíritos noturnos aterrorizam-se quando avistam a espada de um carrasco. De que terror não devem então ser tomados quando se lhes apresenta a Crítica da razão pura de Kant! Esse livro é a espada que matou, na Alemanha, o Deus dos deístas" (Ibid., p. 115). E ainda:

No ano de 1789 , não se tratava mais de outra coisa na Alemanha senão da filosofia de Kant, e ela tinha, então, para o fundo e para a forma, seus comentários, crestomatias, 
interpretações, apreciações, apologias, etc., etc. Basta lançar um olhar para o primeiro catálogo de filosofia que vier: a multidão inumerável de escritos de que Kant foi então objeto testemunha suficientemente o movimento intelectual ao qual esse único homem dera nascimento. [...] Tivemos motins no mundo do pensamento assim como vocês no mundo material, e nos encolerizamos na demolição do velho dogmatismo tanto quanto vocês no ataque à Bastilha. [...] Era uma revolução, e não faltaram os horrores. [...] Kant deu esse grande impulso aos espíritos menos pelo conteúdo de seus escritos do que pelo espírito crítico que neles reinava, e que se introduziu desde então em todas as ciências. Todas as disciplinas foram por ele tomadas; mesmo a poesia não ficou a salvo dessa influência. Schiller, por exemplo, foi um poderoso kantista, e suas concepções artísticas estão impregnadas da filosofia de Kant (Ibid., p. 124).

Se não impossível, era mesmo muito pouco provável que Staël tivesse, à época de De la littérature, um conhecimento mais aprofundado dessa "revolução kantiana" de que se gabará Heine muito mais tarde, sobretudo das implicações da referida revolução no terreno da crítica estética. Como observa Helmreich (2002, p. 46), o conhecimento dos textos kantianos na França dos primeiros decênios do oitocentos é "necessariamente limitado": excetuandose alguns textos secundários, "será preciso esperar o segundo terço do século XIX para poder ler as obras de Kant em língua francesa”. A situação da Kritik der Urteilskraft [Crítica da faculdade do juízo] nesse contexto é ainda mais desfavorável: apenas em 1846 ela ganha uma primeira edição em francês; antes disso, entre os especialistas, ela "permanece na sombra da Crítica da razão pura", explica Helmreich (Ibid., p. 46).

Esse desconhecimento fica patente no breve capítulo de De la littérature dedicado às letras germânicas, no qual Staël observa que se os alemães não possuíam uma pátria política, por outro lado "fizeram para si uma pátria literária e filosófica, para a glória da qual eles são plenos do mais nobre entusiasmo" (STAËL, 1991, p. 268). Se suas observações acerca da literatura alemã 
restringem-se, contudo, na ocasião, a uns poucos autores e obras - basicamente a Goethe, Klopstock e Wieland -, no que se refere à filosofia o quadro é ainda pior: Staël limita-se, sem citar ou deterse num único autor ou obra, a proferir generalidades em si mesmas temerárias, como a de que "não há nação mais singularmente própria aos estudos filosóficos” (Ibid., p. 267), de que a filosofia dos "homens esclarecidos" da Alemanha distinguese por "ter substituído a superstição religiosa pela austeridade da moral" (Ibid., p. 269), de que os alemães, "em sua revolução filosófica, souberam pôr, no lugar das barreiras usadas que tombavam de decrepitude, os limites imutáveis da razão natural" (Ibid., p. 269), de que um "jugo voluntário coloca, contudo, obstáculo, sob alguns aspectos, ao grau de esclarecimento [au degré de lumières] que se poderia adquirir na Alemanha; é o espírito de seita" (Ibid., p. 268) - tudo se passando, pois, como se autora se limitasse a reproduzir impressões de segunda mão a respeito de um estado de coisas em vigor do outro lado do Reno, do qual certamente ouvira falar, sem, contudo, efetivamente conhecer.

A situação será completamente outra, é verdade, por ocasião do surgimento do segundo dos livros fundamentais de Staël, seu tão célebre tratado sobre a Alemanha.

\section{II}

As condições políticas desfavoráveis que teriam finalmente levado a autora a um conhecimento efetivo da Alemanha e à consequente elaboração de sua opus magnum são bem conhecidas. ${ }^{1}$ Banida de Paris por Napoleão em outubro 1803, Staël, que estudava o alemão desde 1799, passará o fim daquele ano e a primavera do próximo na Alemanha; frequentará salões literários, travará contato com grandes homens de letras: em

\footnotetext{
${ }^{1}$ Cf., por exemplo, a introdução de Simone Balayé a STAËL (1968a).
} 
Weimar, com Goethe, com Schiller; em Berlim, com Fichte, com August Schlegel, de quem, aliás, assistirá as célebres conferências sobre arte dramática e literatura proferidas em 1808-1809, em Viena. $O$ projeto de um livro sobre a Alemanha, surgido e alimentado durante o exílio germânico da autora, a ocupará nos anos seguintes, sendo finalmente concluído em 1810. Já impressos os exemplares da primeira edição de De l'Allemagne, eles serão apreendidos pela polícia napoleônica e a obra impedida de vir à luz sob a acusação de ser antifrancesa; o livro é publicado na Inglaterra em 1813, e em Paris, finalmente, no ano seguinte, depois da abdicação de Napoleão. "A Alemanha intelectual quase não é conhecida da França; bem poucos homens de letras entre nós dela se ocuparam", afirma Staël nas observações gerais que precedem o conteúdo principal do livro, acrescentando mais à frente: "Acreditei então que podia haver algumas vantagens em fazer conhecer o país da Europa onde o estudo e a meditação foram levados tão longe que se pode considerálo como a pátria do pensamento" (STAËL, 1968a, p. 47).

Às parcas e imprecisas observações do capítulo alemão de De la littérature substituem-se, agora, as duas partes centrais de $D e$ l'Allemagne, "La littérature et les arts" [A literatura e as artes], "La philosophie et la morale" [A filosofia e a moral]. ${ }^{2}$ A primeira delas passa em revista ao longo de cerca de 300 páginas as grandes realizações literárias da era de Goethe. A segunda procura dar a entender, finalmente, aos franceses, ao longo de mais de cem páginas, a natureza, o escopo e o alcance da "revolução filosófica" da era de Kant.

No capítulo dedicado especificamente à filosofia kantiana, da qual Staël procura "indicar o espírito geral", a autora ressalta tratar-se de "um sistema que ocupa, desde vinte anos, todas as

\footnotetext{
${ }^{2} \mathrm{O}$ conjunto dessas duas partes centrais é precedido por uma primeira parte intitulada "De l'Allemagne e des moeurs des allemands" [Da Alemanha e dos costumes dos alemães] e sucedido de uma parte final intitulada "La religion et le enthousiasme" [A religião e o entusiasmo].
} 
cabeças pensantes da Alemanha" (STAËL, 1968b, p. 138). O impacto revolucionário da trilogia crítica de Kant no horizonte filosófico alemão do final do século XVIII e primórdios do XIX é delineado logo de início por Staël nos seguintes termos:

Seu tratado sobre a natureza do entendimento humano, intitulado Crítica da razão pura, apareceu há cerca de trinta anos, e essa obra permaneceu durante algum tempo desconhecida; mas quando, enfim, descobriram-se os tesouros de ideias que contém, ela produziu uma tal sensação na Alemanha que quase tudo o que se fez desde então, em literatura como em filosofia, vem do impulso dado por essa obra. A esse tratado do entendimento humano sucedeu-se a Crítica da razão prática, que tratava da moral, e a Crítica do julgamento, que tinha a natureza do belo por objeto; a mesma teoria serve de base a esses três tratados, que englobam as leis da inteligência, os princípios da natureza e a contemplação das belezas da natureza e das artes. [...] A filosofia materialista entregava o entendimento humano ao império dos objetos exteriores, a moral ao interesse pessoal, e reduzia o belo a ser apenas agradável. Kant quis restabelecer as verdades primitivas e a atividade espontânea na alma, a consciência na moral, e o ideal nas artes (Ibid., p. 128).

Depois de resumir, à sua maneira, em algumas páginas, as ideias centrais das duas primeiras Críticas, Staël detém-se na terceira, praticamente desconhecida na França nesse início dos oitocentos. "Em seu tratado sobre o sublime e o belo, intitulado: Crítica do julgamento", explica Staël, "Kant aplica aos prazeres da imaginação o mesmo sistema do qual tirou desenvolvimentos tão fecundos na esfera da inteligência e do sentimento, ou, antes, é a mesma alma que ele examina, e que se manifesta nas ciências, na moral e nas belas-artes" (Ibid., p. 136); o entusiasmo pelo belo revela-se, aí, "uma disposição inata, como o sentimento do dever e as noções necessárias do entendimento" (Ibid., p. 137).

Kant rejeita, pois, a explicação dos filósofos materialistas, que "julgam o belo com respeito à impressão agradável que ele 
causa, e o colocam, assim, no império das sensações” (Ibid., p. 136); "encerrado na esfera das sensações, e submetido, por consequência, à diferença de gostos", prossegue Staël, o belo "não poderia merecer esse assentimento universal que é o verdadeiro caráter da beleza" (Ibid., p. 137). Mas Kant rejeita também a outra explicação então corrente, a dos filósofos espiritualistas, que "reportam tudo à razão, veem no belo o perfeito, e nele encontram alguma analogia com o útil e o bom, que são os primeiros degraus do perfeito", afirma Staël (Ibid., p. 136). "Kant, separando o belo do útil, prova claramente que não está, de modo nenhum, na natureza das belas-artes dar lições", conclui a autora noutra parte, acrescentando que "desde que se tem por objeto colocar em evidência um preceito de moral, a livre impressão que produzem as obras-primas de arte é necessariamente destruída” (Ibid., p. 160). E ainda: "Não é certamente por desconhecer o valor moral do que é útil que Kant dele separou o belo; é para fundar a admiração de todo tipo sobre um desinteresse absoluto" (Ibid., p. 161).

Staël conclui o capítulo dedicado à filosofia de Kant afirmando que se pode extrair dos escritos do autor "uma multidão de ideias brilhantes sobre todos os assuntos"; mais do que isso, ela sugere: "é dessa doutrina apenas que é possível tirar agora percepções engenhosas e novas" (Ibid., p. 140). Kant, em suma, ela o diz no começo do capítulo, "soube forjar as armas para aqueles que seriam chamados a combater com elas" (Ibid., p.127). Staël se ocupará, com efeito, na sequência, da "influência da nova filosofia alemã" (a) "sobre a literatura e as artes" [parte III, cap. IX], (b) "sobre as ciências" [parte III, cap. X] e (c) "sobre o caráter dos alemães" [parte III, cap. XI] - divisão essa que reflete claramente a tripartição kantiana das esferas de valor em domínios autônomos: o estético, o cognitivo e o moral.

No domínio estético, a grande lição kantiana sobre a qual então insiste Staël é mesmo a da impossibilidade de se determinar a universalidade do belo com base na agradabilidade do mesmo, a qual, sendo da ordem do sensorial, encontra-se irremediavelmente 
sujeita a variações: "A diversidade dos gostos pode se aplicar ao que é agradável, pois as sensações são a fonte desse gênero de prazer" explica Staël (Ibid., p. 137); e se, de fato, "todos os homens devem admirar o que é belo, seja na arte, seja na natureza" (Ibid., p. 137), então essa universalidade assentaria, necessariamente, noutra base. Segundo Kant, como observará Gadamer (1999, p. 53), "para aprazer como obra de arte, algo deve ser ao mesmo tempo mais do que apenas totalmente agradável ao gosto [geschmackvollgefällig]". Gadamer aí tem em vista o mesmo que Staël meio século antes: a teoria kantiana do "ideal da beleza" [Ideale der Schönbeit] exposta no $§ 17$ da terceira Crítica.

"Ideia significa propriamente um conceito da razão [Vernunftbegriff], e ideal, a representação de um ente individual como adequado a uma ideia”, explica Kant (1974, p. 150); o "arquétipo do gosto" [Urbild des Geschmacks] - que, segundo Kant, cada um produz em si mesmo a fim de julgar tudo o que é objeto do gosto -, se, por um lado, "certamente repousa sobre a ideia indeterminada da razão sobre um máximo”, por outro, "não pode ser representado através de conceitos, mas apenas em apresentação individual [in einzelner Darstellung]", sendo, pois, mais bem denominado "ideal do belo" [Ideal des Schönen]: "se não estamos imediatamente de posse do mesmo, aspiramos, contudo, produzi-lo em nós" (Ibid., p. 150). Em outro ponto, Kant afirma ser preciso tomar em consideração "um certo ideal", o qual "a arte deve ter em vista, embora em seu exercício nunca o alcance completamente" (Ibid., p. 299).

Com essa concepção de um "ideal da beleza", observa Gadamer (1999, p. 55), "Kant destrói o fundamento a partir do qual a estética da perfeição [Vollkommenbeitsästbetik] encontra sua beleza única e incomparável na completa presença aos sentidos [Sinnenfälligkeit] de todo ente"; e ainda: "Só então 'a arte' está apta a tornar-se um fenômeno autônomo. Sua tarefa não é mais a representação do ideal da natureza - mas o encontro do homem consigo mesmo na natureza e no mundo humanohistórico" (Ibid., p. 55). A isso Staël se reporta como o nascimento 
do "ideal", isto é, "o belo, considerado não mais como a reunião e a imitação do que há de melhor na natureza, mas como a imagem realizada do que nossa alma imagina" (STAËL, 1968b, p. 136). Eis aí, poder-se-ia dizer, o acontecimento capital no coração do pensamento alemão sobre as artes, segundo Staël:

Os alemães não consideram, assim como se o faz de ordinário, a imitação da natureza como o principal objeto da arte; é a beleza ideal que lhes parece o princípio de todas as obras-primas, e sua teoria poética está, a esse respeito, absolutamente de acordo com sua filosofia. A impressão que se recebe pelas belas-artes não tem a menor relação com o prazer que uma imitação qualquer faz experimentar; o homem tem na sua alma sentimentos inatos que os objetos reais não satisfarão jamais, e é a esses sentimentos que a imaginação dos pintores e dos poetas sabe dar uma forma e uma vida (Ibid., p. 161-162).

Ao dizê-lo, Staël o faz como quem relata a seus compatriotas uma verdadeira revolução intelectual, ao que tudo indica análoga àquela que, em De la littérature, ela lamentava não ter acompanhado a revolução política de 1789; por outro lado, tornase evidente aí a impossibilidade de que uma tal revolução intelectual se fizesse derivar, simplesmente, da revolução política na França, posto que o abalo causado por esta não poderia mesmo atingir, dada sua natureza, o estrato profundo de consciência em que se realiza a outra: na França pós-revolucionária, a questionabilidade da perspectiva mimética em teoria da arte e das regras de representação e de "bom gosto" a ela associadas avulta como mero efeito colateral da derrocada da classe social em meio à qual elas tinham vigência, não ensejando uma reflexão sobre as condições de possibilidade do juízo de gosto e do sentimento do belo que transcendessem a arena empírica da disputa entre um gosto "aristocrático" e outro "republicano", ou um gosto "do sul" e outro "do norte". Em contrapartida, junto ao pensamento alemão que Staël ora tem em vista, o questionamento do ideal mimético de arte e da preceptística por ele engendrada mostra-se indissociável 
da postulação de um a priori transcendental para o gosto, o qual antes desautoriza do que justifica o estabelecimento de regras pretensamente objetivas que procurem determinar através de conceitos o que seja o belo.

A "teoria literária dos alemães", afirma Staël, "difere de todas as outras no que não assujeita os escritores a usos nem a restrições tirânicos. É uma teoria totalmente criadora, uma filosofia das belas-artes que, longe de constrangê-las, procura, como Prometeu, roubar o fogo do céu para dele fazer presente aos poetas" (Ibid., p. 162). Não há dúvida, apesar de Staël não o explicitar, de que a matriz da teoria literária "tirânica" e "constrangedora" das belas-artes à qual aí se opõe a libertária teoria "criadora" dos alemães é a França; "vale infinitamente mais, me parece, para a literatura de um país" - prossegue, nesse sentido, Staël, -, "que sua poética seja fundada sobre ideias filosóficas, mesmo um pouco abstratas, do que sobre simples regras exteriores; pois essas regras não são senão barreiras para impedir as crianças de caírem" (Ibid., p. 163).

No livro que publica em Paris duas décadas depois do de Staël, em oposição a ele e, provocativamente, portando o mesmo título, Heinrich Heine ${ }^{3}$ afirmará que em De l'Allemagne Staël "não louva a vida intelectual, o idealismo dos alemães, senão para censurar o realismo que dominava, então, entre os franceses, e a

\footnotetext{
3 À época exilado político em Paris (tendo feito o caminho inverso, pois, ao de Staël em 1803), Heine publicara na imprensa local uma série de artigos oferecendo uma visão de seu país natal declaradamente contraposta àquela promulgada por Staël, vindo a reunir esse material em livro em 1835. "Nas três primeiras partes desse livro, falei com algum desenvolvimento das lutas entre a religião e a filosofia na Alemanha; eu tinha que explicar essa revolução intelectual de meu país, sobre a qual Madame de Staël espalhou, de sua parte, tantos erros na França", afirma, com efeito, Heine, no prefácio à primeira edição de seu livro, declarando: "não cessei de ter em vista o livro dessa avó dos doutrinários, e foi com uma intenção de retificação que dei ao meu esse mesmo título: De l'Allemagne" (HEINE, 1998, p. 43).
} 
magnificência material da instituição imperial", o que faria do livro um análogo moderno de Germania, de Cornélio Tácito (56-117 d.C.), autor que, explica Heine, "escrevendo sua apologia dos alemães, quis fazer a sátira indireta de seus compatriotas" (HEINE, 1998, p. 157). Isso pareceria procedente, à primeira vista, em face das citadas passagens em que Staël toma implicitamente a França como parâmetro negativo de avaliação do pensamento estético-literário alemão; a verdade, porém, é que em De l'Allemagne não faltam aproximações explícitas entre as duas discrepantes perspectivas, nas quais, via de regra, Staël assume um posicionamento claramente favorável à perspectiva alemã em matéria de gosto e de crítica, a qual, mais do que reconhecida, deveria mesmo, segundo a autora, ser emulada pelos franceses. "Na Alemanha não há gosto fixo sobre nada, tudo é independente, tudo é individual. Julga-se uma obra pela impressão que dela se recebe, e jamais pelas regras, pois lá não as há admitidas de forma geral: cada autor é livre para se criar uma esfera nova", observa Staël (1968a, p. 159), acrescentando, em contraste: "Na França, a maioria dos leitores não quer jamais ser emocionada, nem mesmo se divertir à custa de sua consciência literária: o escrúpulo lá se refugiou" (Ibid., p. 160); e ainda: "Um autor alemão forma seu público; na França, o público comanda os autores" (Ibid., p. 160).

Num curto capítulo intitulado "Du goût" [Do gosto], o potencial subversivo dessas comparações parece atingir o seu máximo. "Aqueles que se atribuem gosto, disso são mais orgulhosos do que aqueles que se atribuem gênio", observa, de início, Staël, acrescentando mais à frente: "Em todo país onde haverá vaidade, o gosto será colocado em primeiro lugar, porque ele separa as classes e é um signo da reunião entre todos os indivíduos da primeira" (Ibid., p. 247); e ainda: "enfim, pode acontecer que uma nação inteira se coloque como aristocracia de bom gosto perante as outras, e que ela seja ou que ela se creia a única boa companhia da Europa; e é o que pode se aplicar à França, onde o espírito de sociedade reinava tão eminentemente 
que ela tinha alguma desculpa para essa pretensão" (Ibid., p. 247). Staël retruca, então, que "o gosto em sua aplicação às belas-artes difere singularmente do gosto em sua aplicação às conveniências sociais" (Ibid., p. 247), que "o gosto em poesia se deve à natureza e deve ser criador como ela", que "os princípios desse gosto são, pois, totalmente diferentes daqueles que dependem das relações da sociedade" (Ibid., p. 248). Mais à frente, pondera: "Se não se deve transportar para as artes senão a imitação da boa companhia, apenas os franceses o são verdadeiramente capazes; porém, mais liberdade na composição é necessária para agitar fortemente a imaginação e a alma" (Ibid., p. 248). Mais à frente, sentencia: "O bom gosto em literatura é, sob certos aspectos, como a ordem sob o despotismo, importa examinar a que preço se lhe compra" (Ibid., p. 248). Não surpreende que esse trecho, conforme o indica Staël em nota, tenha sido suprimido pela censura.

Como se vê, a reprovação frequentemente mordaz de certos aspectos da vida intelectual francesa que atravessa $D e$ l'Allemagne não é nada "indireta", como quer Heine, o "idealismo dos alemães" sendo aí tomado, na verdade, não como mero pretexto para o ataque ao "realismo dos franceses", mas como uma via efetiva de superação do mesmo, como estímulo e subsídio para a pretendida renovação das letras e do gosto na França pósrevolucionária. É evidente a dimensão política que isso tudo havia de necessariamente assumir sob o regime napoleônico, e não estranha que o livro tenha tido sua publicação impedida pela polícia do imperador sob a acusação de ser antifrancesa. Em suma, o gesto de Staël ao escrever De l'Allemagne não era da ordem da conspiração velada, como sugere Heine, mas da franca revolução, como bem observará Lanson (1912, p. 885) ao comentar o livro: "revolta geral da individualidade contra as regras que a comprimem e as fórmulas que a contrariam: estamos em plena insurreição". É certo que, à luz desse propósito revolucionário maior, impõe-se a Staël matizar a "teoria literária" de inspiração kantiana, fazendo distinções e escolhas, ao invés de simplesmente tomá-la em bloco em contraste com o estado de coisas vigente na França. 
Antes de mais nada, há, da parte de Staël, uma opção pela crítica, segundo ela o "ramo da literatura alemã que foi levado mais longe" (1968b, p. 68). Isso posto, há a preferência por três autores em especial: "Entre os escritores mais jovens, Schiller e os dois Schlegel se mostraram de longe superiores a todos os outros críticos", afirma a autora (Ibid., p. 68). Por fim, há a indisfarçada preferência por um dos três perante os demais: August Schlegel.

"Schiller é o primeiro entre os discípulos de Kant que aplicou sua filosofia à literatura", reconhece Staël (Ibid., p. 68), destacando do autor seus escritos sobre "o ingênuo e o sentimental" [1795-96], nos quais, segundo ela, o talento que ignora a si - isto é, o "ingênuo" -, e o talento que observa a si mesmo - isto é, o "sentimental" - "são analisados com uma sagacidade prodigiosa" (Ibid., p. 69); "mas em seu ensaio sobre a graça e a dignidade [1793] e em suas cartas sobre a Estética [1795], isto é, a teoria do belo, há demasiada metafísica", censura Staël (Ibid., p. 69). "Schiller exerce a literatura por seu talento, e a filosofia por sua propensão à reflexão; seus escritos em prosa estão nos confins das duas regiões", explica Staël, "mas ele frequentemente transpassa para a mais alta delas, e, retornando sem cessar ao que há de mais abstrato na teoria, desdenha a aplicação como uma consequência inútil dos princípios que formulou" (Ibid., p. 69). Daí a preferência por August Schlegel: "Os escritos de A. W. Schlegel são menos abstratos que os de Schiller; como possui, em literatura, conhecimentos raros, mesmo em sua pátria, ele é reconduzido sem cessar à aplicação pelo prazer que encontra em comparar as diversas línguas e as diferentes poesias entre elas" (Ibid., p. 69-70). De Friedrich Schlegel, a quem aí dedica apenas um parágrafo, Staël afirma que "estando ocupado com filosofia, é menos exclusivamente dedicado do que seu irmão à literatura" (Ibid., p. 72).

Poder-se-ia dizer que o critério de avaliação então adotado por Staël na comparação que faz dos autores em questão é o da maior ou menor contribuição dos mesmos para o desenvolvimento da prática crítica. "A descrição animada das obras-primas [la description animée des chefs-d'oeuvre] oferece bem mais interesse à crítica do que as ideias gerais que planam sobre todos os assuntos 
sem caracterizar nenhum", sentencia Staël (Ibid., p. 69) - dando a entender, na sequência, ser a obra crítica de August Schlegel a que encarna exemplarmente esse ideal de uma "descrição animada das obras-primas”. Sobre o célebre curso sobre arte dramática e literatura que ele havia dado em Viena, ${ }^{4} \mathrm{e}$ "que engloba o que foi composto de mais notável pelo teatro desde os gregos até nossos dias", Staël afirma não se tratar de "uma nomenclatura estéril dos trabalhos de diversos autores"; antes: "o espírito de cada literatura é aí apreendido com a imaginação de um poeta” (Ibid., p. 70); e ainda: "Desfruta-se em poucas páginas do trabalho de toda uma vida; cada julgamento trazido pelo autor, cada epíteto dado aos escritores de que ele fala, é belo e justo, preciso e animado" (Ibid., p. 70).

August Schlegel teria encontrado, assim, em suma, "a arte de tratar as obras-primas da poesia como maravilhas da natureza, e de pintá-las com cores vivas que não prejudicam a fidelidade do desenho" (Ibid., p. 70). Não faltaria, bem entendido, à sua análise literária "uma grande profundidade filosófica": mas se "esse gênero de mérito se encontra frequentemente entre os escritores alemães", pondera Staël, "Schlegel não tem equivalente na arte de inspirar o entusiasmo pelos grandes gênios que ele admira” (Ibid., p. 70). Relembrando-se do curso de Viena, no qual estivera presente, Staël admira-se que Schlegel, "longe de se aferrar aos defeitos, eterno alimento da mediocridade ciumenta, procurava somente fazer reviver o gênio criador" (Ibid., p. 71). Para Staël, em síntese: "somente assim que é honorável ser um crítico; todos os homens da profissão bastam para ensinar os defeitos ou as negligências que se devem evitar: mas depois do gênio, o que há de mais semelhante a ele é o poder de conhecê-lo e admirá-lo" (Ibid., p. 72).

${ }^{4}$ Publicado em livro, em três volumes, sob o título de Vorlesungen über dramatische Kunst und Literatur [Lições sobre arte dramática e literatura] (18091811); já em 1814 - no mesmo ano, portanto da publicação de De l'Allemagne em Paris -, é publicada uma tradução do livro para o francês, de autoria de Mme. Necker de Saussure, prima de Mme. de Staël, sob o título de Cours de littérature dramatique [Curso de literatura dramática]. 
Atendo-se ao que Staël deliberadamente destaca e valoriza em August Schegel, sobretudo na comparação com Schiller, dirse-ia que a função determinante do mesmo na economia interna de De l'Allemagne é a de catalisador-bem entendido, entre Kant e o "nouveau régime" crítico de que ela, Staël, se converteria em marco inaugural na França. Desde De la littérature, Staël encontrava-se pessoalmente absorvida pela tarefa de fornecer ao juízo de gosto em seu país um fundamento menos arbitrário do que os velhos preceitos aristocráticos do "bom gosto". Com a terceira Crítica, percebe Staël em De l'Allemagne, Kant afasta o sentimento do belo tanto do "agradável", como queriam os materialistas, quando do "útil" e do "bom", como queriam os espiritualistas, para torná-lo, ela diz, "uma disposição inata, como o sentimento do dever e as noções necessárias do entendimento". Em face do criticismo kantiano, Staël reconhece ser "dessa doutrina apenas que é possível tirar agora percepções engenhosas e novas".

O grande mérito de Kant, diz Staël (1968b, p. 139), "foi o de elevar a dignidade moral, dando por base a tudo o que há de belo no coração uma teoria fortemente racional". Em vista do que Staël pondera na sequência, não seria tarefa nada simples ou óbvia mobilizar tal teoria em favor de uma nova prática crítica - a começar pelas dificuldades impostas pelo estilo de Kant, que, segundo a autora, "serviu-se de uma terminologia muito difícil de compreender e do neologismo o mais fatigante" (Ibid., p. 139). Kant, avalia Staël, "mostra em seus escritos uma força de imaginação em metafísica [une force de tête en métaphysique] que o posiciona, a esse respeito, no primeiro lugar dos pensadores" (Ibid., p. 139); mas essa mesma força que garante a Kant sua glória filosófica implicaria, por outro lado, um sério obstáculo à compreensão de sua filosofia: "Nos objetos os mais claros por eles mesmos, Kant toma frequentemente por guia uma metafísica muito obscura, $\mathrm{e}$ não é senão nas trevas do pensamento que ele carrega uma tocha luminosa" (Ibid., p. 139).

Isso posto, dever-se-ia saber enxergar na apresentação que Staël faz das ideias de Kant, mais especificamente na terceira 
Crítica, um exercício de interpretação ativa dessa "metafísica obscura", no sentido de dela "tirar percepções engenhosas e novas" em prol de uma prática crítica renovada. Otfried Höffe observa a propósito que na França "nenhuma obra marcou tanto a compreensão da filosofia kantiana e em geral do pensamento alemão quanto o livro De l'Allemagne de Madame de Staël", acrescentando: "Certamente, Kant aqui já é interpretado como reação do sentimento contra o racionalismo e como começo do romantismo" (HÖFFE, 2007, p. 298).

$\mathrm{Na}$ altura em que Staël escrevia seu livro, na própria Alemanha difundia-se o pensamento da "escola romântica" sediada em Iena, alicerçado, em suas linhas gerais, na pretensa superação da filosofia kantiana pelas duas principais filosofias idealistas surgidas depois dela: a de Fichte e a de Schelling. Diferentemente, contudo, do grupo reunido em torno dos irmãos Schlegel, Staël não se deixará empolgar pela obra dos dois filósofos, os quais, ela explica, gabaram-se de ter simplificado o sistema de Kant, quando colocaram, na verdade, em seu lugar, "uma filosofia mais transcendente ainda" (STAËL, 1968b, p. 145). Kant havia operado a separação entre "entendimento" e "sensibilidade" - por consequência, entre ciência e moral -, ou, como quer Staël, entre o império da "alma" e o das "sensações"; pois bem, prossegue a autora, "esse dualismo filosófico era fatigante para os espíritos que amam repousar nas ideias absolutas" (Ibid., p. 145-146); e ainda: "Dos gregos a nossos dias repetiu-se frequentemente esse axioma, Que tudo é um, e os esforços dos filósofos sempre tenderam a encontrar num único princípio, na alma ou na natureza, a explicação do mundo" (Ibid., p. 146).

Diferentemente de Kant, que se ateve aos limites daquilo que o espírito poderia, efetivamente, conhecer, e que não seguiu tão profundamente na metafísica "senão para empregar os próprios meios que ela oferece de modo a demonstrar sua insuficiência" (Ibid., p. 129), Fichte e Schelling, por sua vez, em busca do princípio único absoluto que tudo explicaria, "abandonaram a esfera de nós-mesmos [la sphère de nous-mêmes] e quiseram se 
elevar até conhecer o sistema do universo" (Ibid., p. 146). "Eu não sei porque se encontra mais elevação filosófica na ideia de um único princípio, seja material, seja intelectual", indaga Staël, e retruca: "nosso sentimento concorda mais com os sistemas que reconhecem como distintos o físico e o moral" (Ibid., p. 146). Staël insurge-se particularmente contra o sistema fichtiano em torno do "EU" absoluto - essa "alma inabalável" à qual "Fichte atribui o dom da imortalidade e o poder de criar, ou, para traduzir mais exatamente, de irradiar nela mesma a imagem do universo" (Ibid., p. 147) -, sistema, segundo ela, "singularmente difícil de seguir": "Ele despoja as ideias das cores que servem tão bem para lhes fazer compreender; e as belas-artes, a poesia, a contemplação da natureza desaparecem nessas abstrações sem mistura de imaginação nem de sensibilidade" (Ibid., p. 147).

O fato, contudo, é que foi justamente a chamada "Doutrina da ciência" [Wissenschaftslehre] fichtiana, mais tarde suplementada pela "Filosofia da natureza" [Naturphilosophie] schellinguiana, que precipitou, no âmbito do pensamento romântico alemão, aquela transição do "ponto de vista do gosto" para o "ponto de vista do gênio" de que falará Gadamer (1999), e que é constitutiva da "teoria literária" que tanta admiração desperta em Staël. E se não pela via direta do idealismo filosófico póskantiano, haveria mesmo de se dar por outra via a conversão staëliana, por assim dizer, à referida transição: aquela do crítico literário por demais imbuído de Fichte e Schelling para condescender com o grande limite imposto ao "gênio" por Kant na terceira Crítica, isto é, seu assujeitamento perante a natureza - August Schlegel. Como observa Wellek a propósito:

Kant, segundo Schlegel, faz do gênio um mero instrumento cego da natureza. É verdade que há algo na arte que não pode ser aprendido, mas o propósito e todos os motivos que podem incitar nossa livre atividade influenciam o exercício da arte. As grandes obras de arte, tais como as tragédias gregas, surgiram como o resultado 
de competições. Toda criação é simultaneamente julgamento, toda expressão de poder criativo está relacionada a constante introspecção. O gênio é a conexão íntima do inconsciente e da atividade autoconsciente do espírito humano, de instinto e intenção, de liberdade e necessidade. O gênio abrange a totalidade do homem interior, todos os seus poderes: não apenas sua fantasia (Einbildungskraft) e entendimento (Verstand), mas também sua imaginação (Fantasie) e razão (Vernunft) (WELLEK, 1955, p. 46).

É forçoso reconhecer que os elogios de Staël à capacidade crítica de August Schlegel enfatizam justamente seu poder de conhecer e admirar o "gênio", seu talento, segundo ela, de "fazer reviver o gênio criador" e de inspirar, como ninguém, "o entusiasmo pelos grandes gênios que ele admira", emitindo sobre os autores lidos um julgamento "belo e justo, preciso e animado". Eis a quintessência, pois, do ideal staëliano de crítica como “descrição animada das obras-primas", ideal esse que, Wellek (Ibid., p. 227) observa de passagem, ela própria, em De l'Allemagne, "realiza muito frequentemente".

A certa altura de seu livro, Staël sentencia: "il faut, en littérature, tout le goût qui est conciliable avec le génie”, é preciso, em literatura, todo o gosto que é conciliável com o gênio (Ibid., p. 248); entre gosto e gênio, não deveria haver dúvida, pois, a qual deles cabe a prevalência: ao segundo, devendo o primeiro com ele "conciliar-se". Essa máxima não apenas sintetiza lapidarmente o ponto de vista de Staël como dá o tom programático da drástica renovação da crítica que teria lugar na França a partir de $D e$ l'Allemagne: "um belo e forte livro", observa, em suma, Lanson (1912, p. 883), que "funda a crítica romântica". 


\section{REFERÊNCIAS}

BRUNETIÈRE, F. L'évolution des genres dans l'bistoire de la littérature. Paris: Pocket, 2000 [1890].

GADAMER, H.-G. Wabrbeit und Methode: Grundzüge einer philosophischen Hermeneutik. (Gesammelte Werke. Band 1.) Tübingen: Mohr Siebeck, 1999 [1960]. [Ed. bras.: GADAMER, Hans-Georg. Verdade e método: traços fundamentais de uma hermenêutica filosófica. 10. ed. Trad. Flávio Paulo Meurer. Petrópolis: Vozes, 2008.]

HEINE, H. De l'Allemagne. Paris: Gallimard, 1998 [1835].

HELMREICH, C. La réception cousinienne de la philosophie esthétique de Kant: contribution à une histoire de la philosophie française au XIXe siècle. Revue métaphysique et de morale, n. 34, p. 43-60, 2002.

HÖFFE, O. Immanuel Kant. 7. Aufl. München: C. H. Beck oHG, 2007. [Ed. bras.: HÖFFE, O. Immanuel Kant. Trad. Christian V. Hamm e Valério Rohden. São Paulo: Martins Fontes, 2005.]

KANT, I. Kritik der Urteilskraft. Frankfurt am Main: Suhrkamp, 1974 [1790]. [Ed. bras.: KANT, I. Crítica da faculdade do juízo. Trad. Valério Rohden. 2. ed. Rio de Janeiro: Forense Universitária, 2002.]

LANSON, G. Histoire de la littérature française. 12. ed. Paris: Hachette, 1912 [1894].

STAËL, Madame de. De l'Allemagne. v. 1. Paris: Flammarion, 1968a [1810/1814].

STAËL, M. de. De l'Allemagne. v. 2. Paris: Flammarion, 1968b [1810/ 1814].

STAËL, M. de. De la littérature considérée dans ses rapports avec les institutions sociales. Paris: Flammarion, 1991 [1800].

WELLEK, R. A History of Modern Criticism: 1750-1950. v. II. The Romantic Age. New Haven: Yale University Press, 1955. [Ed. bras.: WELLEK, René. História da crítica moderna. O romantismo. Trad. Lívio Xavier. São Paulo: EdUSP, 1967.]

Recebido para publicação em 28 de dezembro de 2012. Aprovado em 7 de maio de 2013. 